\title{
THE ROLE OF THE NERVOUS SYSTEM IN THE MAINTENANCE
}

\section{OF PULMONARY ARTERIAL HYPERTENSION IN HEART FAILURE}

\author{
BY \\ D. HALMÁGYI, B. FELKAI, J. IVÁNYI, T. ZSÓTÉR, M. TÉNYI, Zs. SZÜCS \\ From the First and Second Departments of Medicine, University Medical School, Szeged, Hungary \\ Received May 20, 1952
}

Elevation of pressure in the pulmonary veins, with a consequent elevation of pressure in the pulmonary capillaries and pulmonary artery has for many years been invoked to explain pulmonary hypertension in both mitral stenosis and left ventricular failure. Ignoring the possibility of pulmonary vasoconstriction, this hypothesis was in complete accordance with the "mechanistic" concept of the regulation of pulmonary pressure, emphasized recently by Cournand $(1947,1950)$ and Hamilton (1951). It was based mainly on the relative refractoriness of the pulmonary circulation towards substances affecting the systemic circulation.

It was soon established, however, that elevation of the pulmonary venous pressure is only partly responsible for the high pressure in the pulmonary artery that is observed in heart failure. Elevation of pulmonary " capillary" pressure beyond the colloid osmotic pressure of plasma causes an increase in the pulmonary pressure gradient (Dexter et al., 1950), as a result of an increase of the pulmonary arteriolar resistance. Lewis et al. (1952), emphasize that in mitral stenosis this increased arteriolar resistance is a physiological counterpart to the anatomical changes observed in the small pulmonary arteries by Parker and Weiss (1936) and Larrabee et al. (1949). In face of this "static" theory of increased pulmonary arteriolar resistance it seems hard to understand why the presence or absence of heart failure raises or lowers the pressure in the pulmonary artery, presumably without a change in the size of the stenosed orifice (Bloomfield et al., 1949 ; Bayliss et al., 1951), or in the lumen of the "statically" narrowed pulmonary arterioles. Not even an increase of the circulating blood volume explains this apparent contradiction. Nor does the decrease of pulmonary arteriolar resistance following mitral commissurotomy (Draper et al., 1951 ; Dexter, 1952) favour this theory. On the other hand, no corresponding narrowing of the pulmonary vessels can be demonstrated in hypertensive heart failure despite a similar elevation of pulmonary arteriolar resistance (Borden et al., 1950). These data seem sufficient to support the view that anatomical factors alone cannot account for all the increase in pulmonary arterial pressure. The mechanism of this reversible elevation of pulmonary vascular resistance, therefore, needs further study.

Anoxia, by producing widespread vasoconstriction in all parts of the circulation, elevates also pulmonary vascular resistance (Motley et al., 1947 ; Liljestrand, 1948 ; Dirken and Heemstra, 1948 ; Doyle et al., 1951, etc.). Pulmonary hypertension following the administration of histamine was also observed in dogs by Dixon and Hoyle (1930). The vasomotor response to both these stimuli is a consequence of their direct chemical action on the pulmonary vessels. The significance of the nervous system as a source of vasomotor stimuli affecting the pulmonary circuit is generally underestimated. Kuntz. (1946) stated that the pulmonary artery and its branches are more richly supplied with nerves than the usual anatomical descriptions and the results of physiological experiments seem to indicate. This statement is corroborated by the observations of Takino (1933), 
Larsell and Dow (1933), Gaylor (1934), Hochrein (1938), Daly and Hebb (1942, 1952), Sternberg and Tamari (1928), Pearce and Witteridge (1951), and many others. The circulatory adjustments existing between the pulmonary circuit and the different parts of the systemic circulation (Schwiegk, 1935 ; Parin, 1943-44 ; Puder, 1938, 1942 ; Scherf and Schönbrunner, 1937) offer a good support for the functional importance of the nerve supply of the pulmonary circulation.

The work of Greene and Bunnell (1950) and Fowler et al. (1951) seemed to indicate that nervous stimuli may contribute to the pathogenesis of pulmonary hypertension in heart failure, for administration of tetra-ethylammonium bromide resulted in a decrease in the pressure of the pulmonary artery and in the resistance of the pulmonary arterioles.

In face of these confusing data, an attempt was made to clarify the position as follows.

(1) A substance was sought capable of raising the pressure in the pulmonary artery without affecting significantly the cardiac output and the systemic arterial circulation. Histamine and anoxia do not correspond to these requirements because of the confusing number of their effects on the circulation. Investigating the effect of ergotamine in the dog, Vargas and Savilla (1949) observed a rise in pulmonary arterial pressure. Because of the untoward effects inherent in the administration of this drug, it was decided to investigate the effect of dihydro-ergotamine (DHE) on the pressure in the pulmonary artery, in man.

(2) New evidence was sought to demonstrate the existence of pulmonary vasoconstriction in heart failure. Sodium nitrite was given, because of its well known direct chemical effect on various vessels.

(3) Finally it was decided to investigate the effect of ganglionic, sympathetic, and central nervous blocking on pulmonary hypertension in heart failure.

\section{MethodS AND MATERIAL}

Investigations were carried out on 43 men and women, in the early morning hours, at least eight hours after the intake of their last meal. Thirty-six of them suffered from chronic congestive heart failure. Before the observations, barbiturate was administrated in a dose of $0.10 \mathrm{~g}$. by intramuscular injection.

Cardiac catheterization was performed in all the cases, in the usual manner, as described before (Halmágyi et al., 1952). The tip of the catheter was placed in the right ventricle or in the pulmonary artery. Oxygen consumption was measured electrically by using a Noyons type of diapherometer (Kipp and Zonen, Delft, Holland). Arterio-venous oxygen difference was determined photoelectrically (Issekutz Jr., et al., 1949). All pressure measurements were done with a Sanborn electromanometer (Rappaport and Sarnoff, 1949).

The term " pulmonary arterial pressure" indicates in this study the systolic pressure of the right ventricle or that of the pulmonary artery.

Pulmonary and peripheral arterial systolic resistances were calculated by using the following equation (Riley et al., 1948) :

$$
R=\frac{P \times 1332 \times 60}{C I}
$$

where

$R=$ resistance in the pulmonary or systemic circuit, dyne $/ \mathrm{sec} . / \mathrm{cm} .-5 / \mathrm{m}^{2}$ body surface area (BSA), $P=$ systolic pressure in the pulmonary or systemic arteries, in $\mathrm{mm} . \mathrm{Hg}$, and

$C I=$ cardiac index, $\mathrm{ml} . / \mathrm{min}$.

If not stated otherwise, substances were administered by a slow intravenous, intracardiac, or intrapulmonary injection by means of an electric pressure pump. These different ways of administration did not significantly modify their effect.

The dose of DHE (Sandoz) was $1.0 \mathrm{mg}$., and that of sodium nitrite $400-600 \mathrm{mg}$. The effect of ganglionic and sympathetic blocking on pulmonary pressure was studied by administering 
tetra-ethylammonium bromide (TEAB), $2-3 \mathrm{mg}$. per $\mathrm{kg}$. body weight, and $N, N$,-dibenzyl- $\beta$ chloroaethylamine- $\mathrm{HCl}$ (dibenamine), $0.5-2.0 \mathrm{mg}$. per $\mathrm{kg}$. body weight, the latter with a speed of $0.05 \mathrm{mg}$. per $\mathrm{kg}$. body weight per min. The role of the central nervous system in maintaining pulmonary arterial hypertension was studied during sleep. The methods, with which sleep was induced, and the criteria for optimal sleep are described in an earlier paper (Halmágyi et al., 1952)

Since different causes act in establishing pulmonary hypertension in the failure of the left ventricle and mitral stenosis it was hoped that the comparison of the effect of similar substances on these two, ætiologically different, but dynamically identical, forms of pulmonary hypertension would help us to distinguish the peripheral and pulmonary causes of the changes observed.

TABLE I

The Effect of Various Agencies on Heart Rate, Systemic Arterial and Pulmonary Pressures and Cardiac Output in Chronic Heart Failure

\begin{tabular}{|c|c|c|c|c|c|c|c|c|c|c|c|c|c|c|c|}
\hline \multirow[t]{2}{*}{ 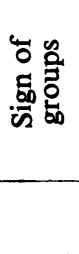 } & \multirow[t]{2}{*}{ 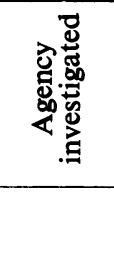 } & \multirow[t]{2}{*}{ Diagnosis } & \multirow[t]{2}{*}{ 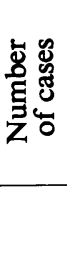 } & \multicolumn{3}{|c|}{$\begin{array}{l}\text { Mean heart } \\
\text { rate }\end{array}$} & \multicolumn{3}{|c|}{$\begin{array}{c}\text { Mean systolic } \\
\text { arterial } \\
\text { pressure, } \\
\text { mm. Hg }\end{array}$} & \multicolumn{3}{|c|}{$\begin{array}{c}\text { Mean systolic } \\
\text { pulmonary } \\
\text { arterial } \\
\text { pressure, } \\
\text { mm. Hg }\end{array}$} & \multicolumn{3}{|c|}{$\begin{array}{l}\text { Mean cardiac } \\
\text { index } \\
\text { lit/min. }\end{array}$} \\
\hline & & & & $b$ & $a$ & $d$ & $b$ & $a$ & $d$ & $b$ & $a$ & $d$ & $b$ & $a$ & $d$ \\
\hline A & DHE & $\begin{array}{c}\text { Mostly } \\
\text { normals }\end{array}$ & 10 & 86 & 84 & -2 & 124 & 128 & +4 & 23 & 32 & +9 & $\overline{4 \cdot 24}$ & $4 \cdot 18$ & -0.06 \\
\hline \multirow[b]{2}{*}{ B } & \multirow{2}{*}{$\begin{array}{c}\text { Sodium } \\
\text { nitrite }\end{array}$} & $\begin{array}{c}\text { Mitral } \\
\text { stenosis }\end{array}$ & 4 & 94 & 88 & -6 & 121 & 115 & -6 & 50 & 45 & -5 & $2 \cdot 74$ & 3.04 & +0.30 \\
\hline & & $\begin{array}{l}\text { Left heart } \\
\text { failure }\end{array}$ & 5 & 91 & 89 & -2 & 139 & 132 & -7 & 71 & 58 & -13 & $2 \cdot 42$ & 2.67 & +0.25 \\
\hline \multirow{2}{*}{ C } & \multirow{2}{*}{ TEAB } & $\begin{array}{l}\text { Mitral } \\
\text { stenosis }\end{array}$ & 5 & 73 & 81 & +8 & 111 & 101 & -10 & 42 & 31 & -11 & $3 \cdot 16$ & 3.60 & +0.44 \\
\hline & & $\begin{array}{l}\text { Left heart } \\
\text { failure }\end{array}$ & 5 & 88 & 93 & +5 & 171 & 135 & -36 & 39 & 31 & -8 & $2 \cdot 87$ & $2 \cdot 87$ & 0.00 \\
\hline \multirow{2}{*}{ D } & \multirow{2}{*}{$\begin{array}{l}\text { Diben- } \\
\text { amine }\end{array}$} & $\begin{array}{c}\text { Mitral } \\
\text { stenosis }\end{array}$ & 4 & 71 & 71 & 0 & 129 & 121 & -8 & 40 & 29 & -11 & $4 \cdot 30$ & 4.63 & +0.33 \\
\hline & & $\begin{array}{l}\text { Left heart } \\
\text { failure }\end{array}$ & 4 & 91 & 87 & -4 & 169 & 153 & -16 & 51 & 40 & -11 & $4 \cdot 36$ & $4 \cdot 11$ & -0.25 \\
\hline \multirow{2}{*}{ E } & \multirow{2}{*}{ Sleep } & $\begin{array}{c}\text { Mitral } \\
\text { stenosis }\end{array}$ & 3 & 91 & 82 & -9 & 120 & 108 & -12 & 74 & 53 & -21 & $2 \cdot 93$ & $3 \cdot 20$ & +0.27 \\
\hline & & $\begin{array}{l}\text { Left heart } \\
\text { failure }\end{array}$ & 3 & 88 & 80 & -8 & 132 & 107 & -25 & 50 & 32 & -18 & $2 \cdot 54$ & 2.79 & +0.25 \\
\hline
\end{tabular}

$b=$ before, $a=$ after, and $d=$ difference between the two previous values.

$\mathrm{DHE}=$ dihydro-ergotamine. $\mathrm{TEAB}=$ tetra-ethylammonium bromide.

Owing to the many groups of individual experiments, a form of tabulation was devised, allowing an easy survey of the results. Tables I and II show mean values of the individual experiments. Groups B-E were divided in two sub-groups. The sub-group " mitral stenosis" consisted of cases where clinical, X-ray, and cardiographic evidence, and in some cases digital palpation during surgical valvotomy, permitted the diagnosis of pure or predominant mitral stenosis. The sub-group of "left heart failure" consisted of patients with mitral and aortic regurgitation, hypertension, and heart failure due to coronary disease and arteriosclerosis. 


\section{RESULTS}

The detailed results are shown in Tables I and II. Only some main features are emphasized below.

The significant increase in pulmonary pressure and resistance observed following the administration of DHE (Tables I and II, Group A, Fig. 3 and 4) appeared within a few minutes and could still be demonstrated after an hour. It remained uninfluenced by TEAB, but dropped promptly to normal levels after the administration of sodium nitrite (Fig. 1).

TABLE II

The Effect of Various Agencies on Peripheral and Pulmonary Systolic Resistance in Heart Failure

\begin{tabular}{|c|c|c|c|c|c|c|c|c|c|}
\hline \multirow[t]{2}{*}{ 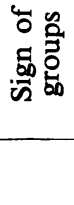 } & \multirow[t]{2}{*}{ 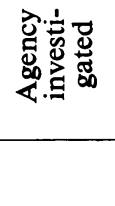 } & \multirow[t]{2}{*}{ Diagnosis } & \multirow[t]{2}{*}{ 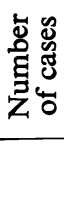 } & \multicolumn{3}{|c|}{$\begin{array}{l}\text { Peripheral systolic } \\
\text { resistance, dyne/sec./ } \\
\mathrm{cm} .^{-5} / \mathrm{m}^{2}{ }^{2} \mathrm{BSA}\end{array}$} & \multicolumn{3}{|c|}{$\begin{array}{c}\text { Total pulmonary } \\
\text { systolic resistance, } \\
\text { dyne } / \mathrm{sec}_{\mathrm{B}} / \mathrm{cm}^{-5} / \mathrm{m}^{2} \\
\text { BSA }\end{array}$} \\
\hline & & & & $b$ & $a$ & $d$ & $b$ & $a$ & $d$ \\
\hline A & DHE & $\begin{array}{c}\text { Mostly } \\
\text { normals }\end{array}$ & 10 & 2,320 & 2,460 & +140 & 435 & 612 & +177 \\
\hline \multirow{2}{*}{ B } & \multirow{2}{*}{$\begin{array}{c}\text { Sodium } \\
\text { nitrite }\end{array}$} & $\begin{array}{c}\text { Mitral } \\
\text { stenosis }\end{array}$ & 4 & 3,540 & 3,003 & -537 & 1,605 & 1,300 & -305 \\
\hline & & $\begin{array}{l}\text { Left heart } \\
\text { failure }\end{array}$ & 5 & 4,580 & 3,980 & -600 & 2,350 & 1,738 & -612 \\
\hline \multirow{2}{*}{ C. } & \multirow{2}{*}{ TEAB } & $\begin{array}{l}\text { Mitral } \\
\text { stenosis }\end{array}$ & 5 & 3,090 & 2,250 & -840 & 1,062 & 689 & -373 \\
\hline & & $\begin{array}{l}\text { Left heart } \\
\text { failure }\end{array}$ & 5 & 4,780 & 3,420 & $-1,360$ & 1,080 & 865 & -215 \\
\hline \multirow{2}{*}{ D } & \multirow{2}{*}{$\begin{array}{l}\text { Diben- } \\
\text { amine }\end{array}$} & $\begin{array}{c}\text { Mitral } \\
\text { stenosis }\end{array}$ & 4 & 2,400 & 2,095 & -305 & 755 & 500 & -255 \\
\hline & & $\begin{array}{l}\text { Left heart } \\
\text { failure }\end{array}$ & 4 & 3,100 & 2,970 & -130 & 937 & 780 & -157 \\
\hline \multirow{2}{*}{$\mathrm{E}$} & \multirow{2}{*}{ Sleep } & $\begin{array}{l}\text { Mitral } \\
\text { stenosis }\end{array}$ & 3 & 3,280 & 2,700 & -580 & 2,020 & 1,350 & -670 \\
\hline & & $\begin{array}{l}\text { Left heart } \\
\text { failur? }\end{array}$ & 3 & 4,170 & 3,070 & $-1,100$ & 1,580 & 917 & -663 \\
\hline
\end{tabular}

$b=$ before, $a=$ after, $d=$ difference between the two previous values.

$\mathrm{DHE}=$ dihydro-ergotamine. $\mathrm{TEAB}=$ tetra-ethylammonium bromide.

The administration of sodium nitrite was followed by a significant decrease in pulmonary pressure and resistance both in mitral stenosis and left heart failure (Tables I and II, Group B, Fig. 3 and 4). No relationship was found, however, between the decrease of systemic and pulmonary pressures (Fig. 5). The decrease in pulmonary artery pressure lasted about 30-50 minutes.

The decrease in pulmonary resistance following TEAB in mitral stenosis was significantly lower than that observed in left ventricular failure. A similar difference could be demonstrated after the administration of dibenamine (Tables I and II, Groups C and D, Fig. 3 and 4). This fact implies that the simultaneous decrease in peripheral resistance bears no relationship to the resulting pulmonary hypotension. The absence of much increase in cardiac output after TEAB may be explained by the small dose used in our experiments. The decrease in pulmonary pressure following TEAB lasted 15-25 minutes. 




FIG. 1.-The effect of sodium nitrite and TEAB on DHE-induced pulmonary pressure elevation.

Dibenamine was effective in reducing pulmonary pressure and resistance in a dose which is generally regarded as insufficient to evoke therapeutic effects. The decrease of pulmonary pressure occurred a few minutes after the administration of the drug had been completed, before mydriasis, coryza, significant arterial hypotension (Nickerson et al., 1948), or venous hypotension (Fejfar and Brod, 1951 ; Halmágyi et al., 1952) had appeared.

The most significant decrease in pulmonary pressure and resistance was observed during sleep (Tables I and II, Group E, Fig. 3 and 4). Pulmonary pressure returned to pre-existing levels promptly after waking the patient (Fig. 2).

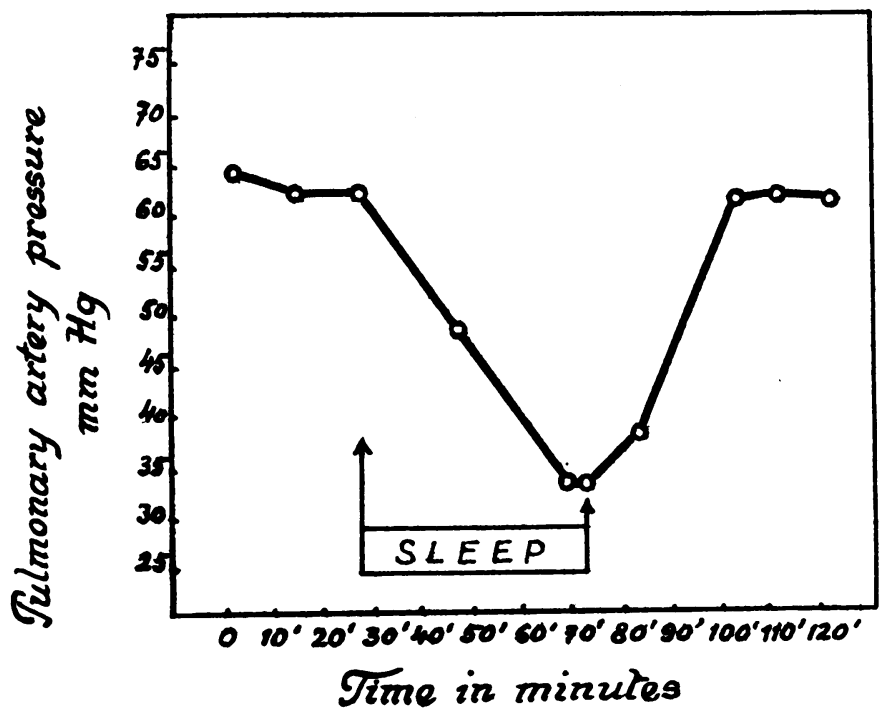

FIG. 2.-The effect of sleep on pulmonary artery pressure in chronic congestive heart failure. 


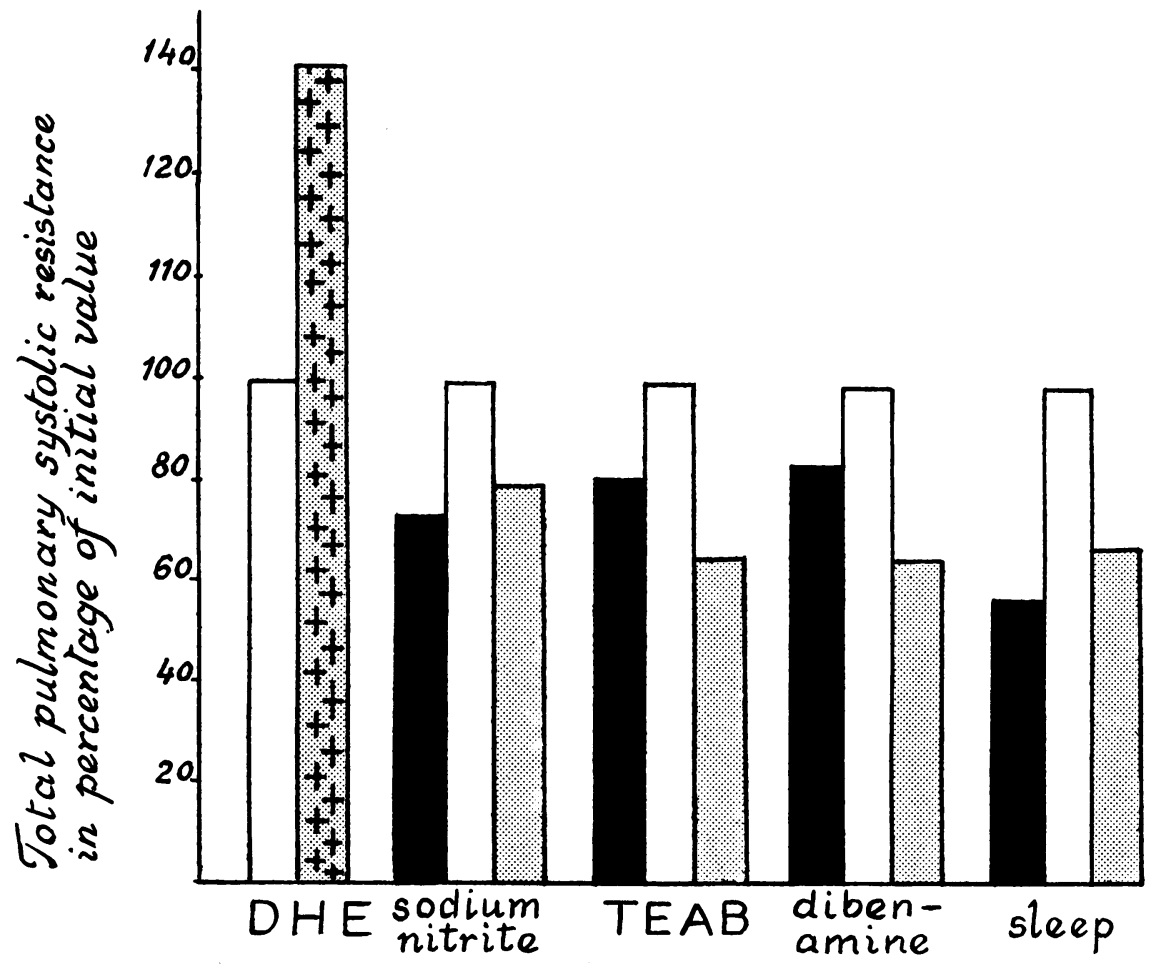

Summation of the effects of all agencies in left heart failure and mitral stenosis.

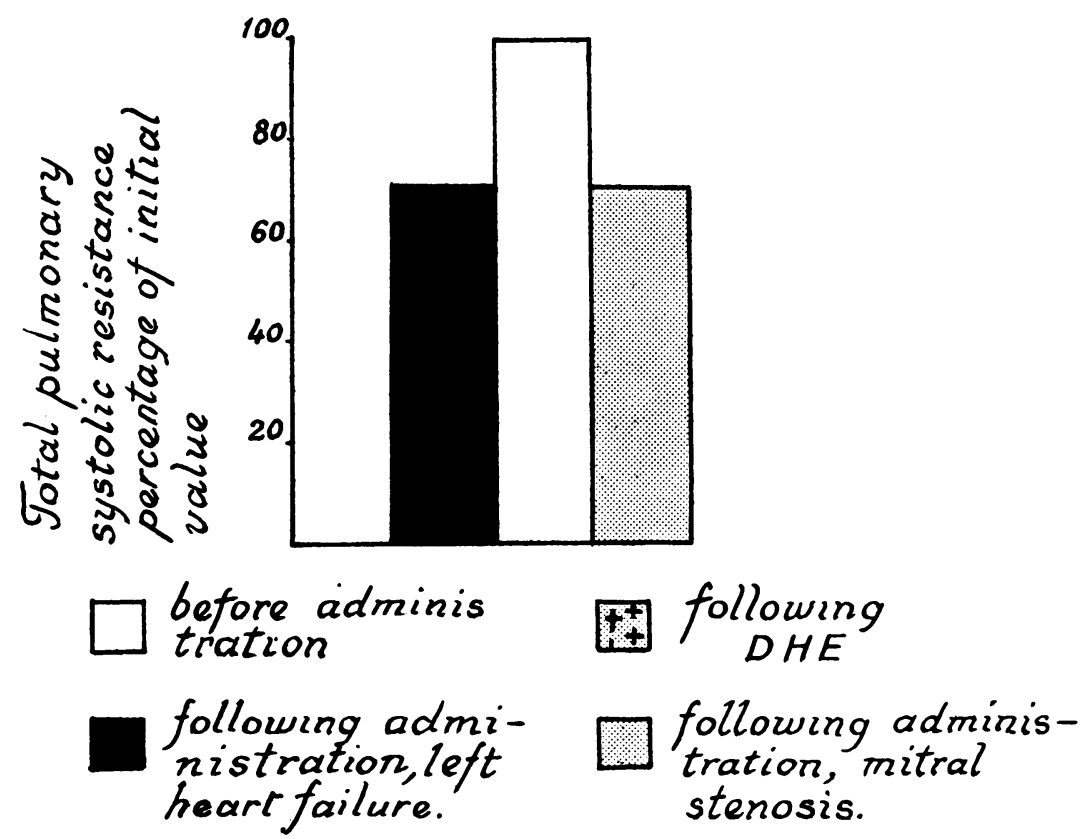

Fig. 3.-Percentage change in total pulmonary systolic resistance following various agencies. 
By summarizing the effect of all these agencies on pulmonary resistance in mitral stenosis and left heart failure, it was found that the decrease was equal in both groups (Fig. 3 and 4).

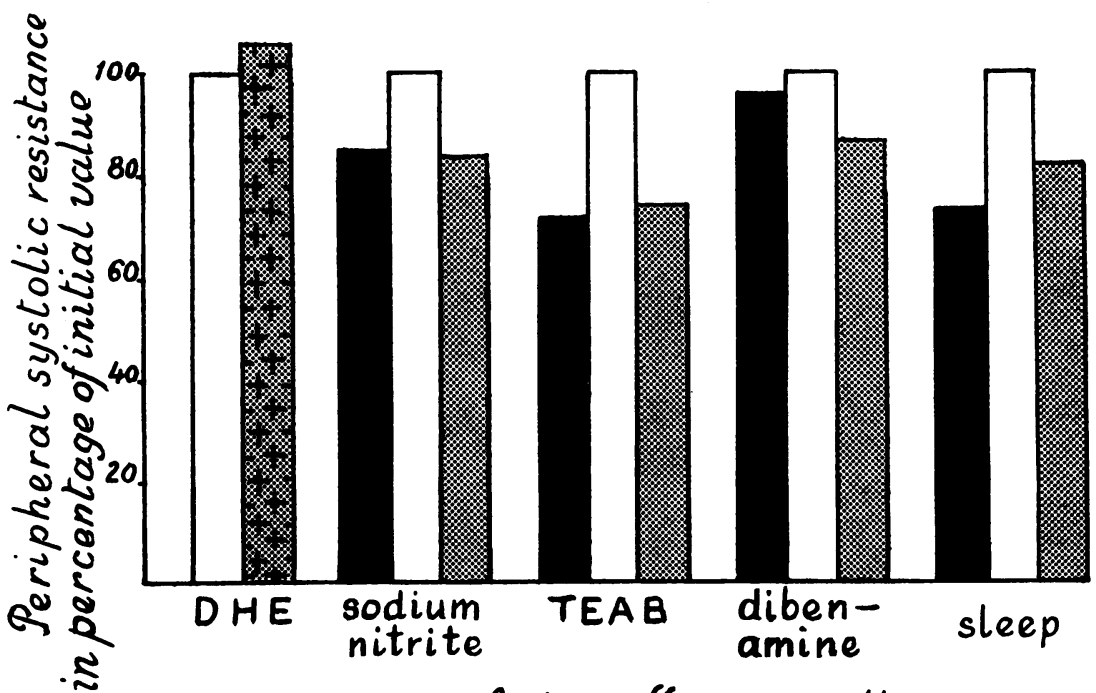

Summation of the effects of all agencies in left heart failure and mitral stenosis.

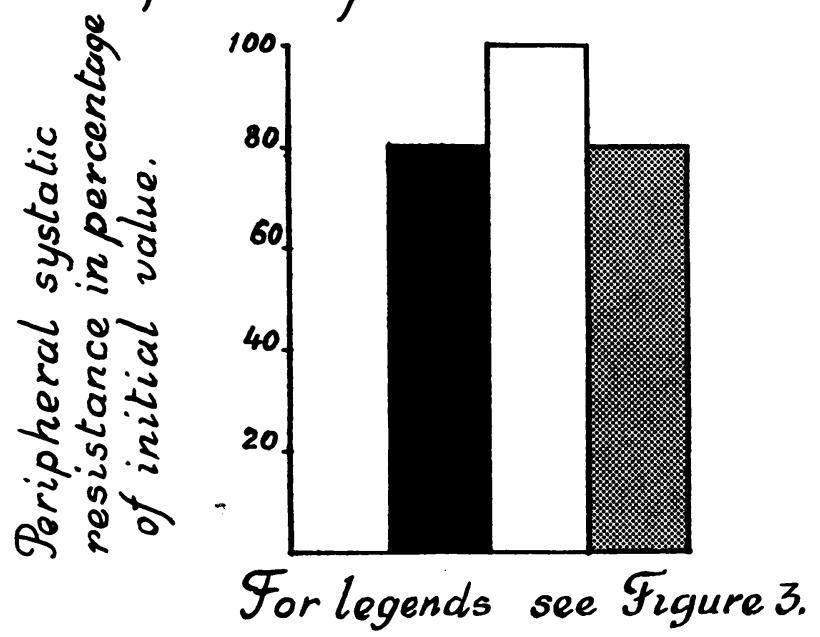

Fig. 4.-Percentage change in peripheral systolic resistance following various agencies in heart failure. Peripheral systolic resistance in percentage of initial value. For legends see Fig. 3.

\section{Discussion}

DHE elevates pulmonary arterial systolic pressure and resistance without affecting the systemic circulation. This effect seems to be due to pulmonary vasoconstriction : it is completely reversed by sodium nitrite. DHE induces pulmonary vasoconstriction by a direct chemical action : TEAB neither prevents nor abolishes pulmonary hypertension following the administration of DHE.

Earlier investigators failed to observe any effect of sodium nitrite or related compounds on the pressure in the pulmonary artery (Cournand, 1947 ; Hamilton, 1951). All these former experi- 
ments were carried out on normal men and animals: sodium nitrite causes a dilatation of constricted vessels only and the pulmonary vessels in normal men and animals are not constricted. The decrease in pulmonary pressure in heart failure following the administration of sodium nitrite may be regarded therefore as a good proof of the existing pulmonary vasoconstriction. The thickening of the smaller arteries in mitral stenosis (Larrabee et al., 1949) and in mitral insufficiency (Becker et al., 1951) is caused in part by muscular tissue. Our findings constitute, therefore, the physiological counterpart of this anatomical evidence of muscular hypertrophy of the pulmonary vessels in heart failure.

The effect of dibenamine and that of TEAB corroborates the assumption that the origin of this vasoconstriction is neurogenic, and is mediated by the sympathetic nervous system. In face of the rapid effect of small doses of dibenamine on pulmonary pressure one is inclined to suppose

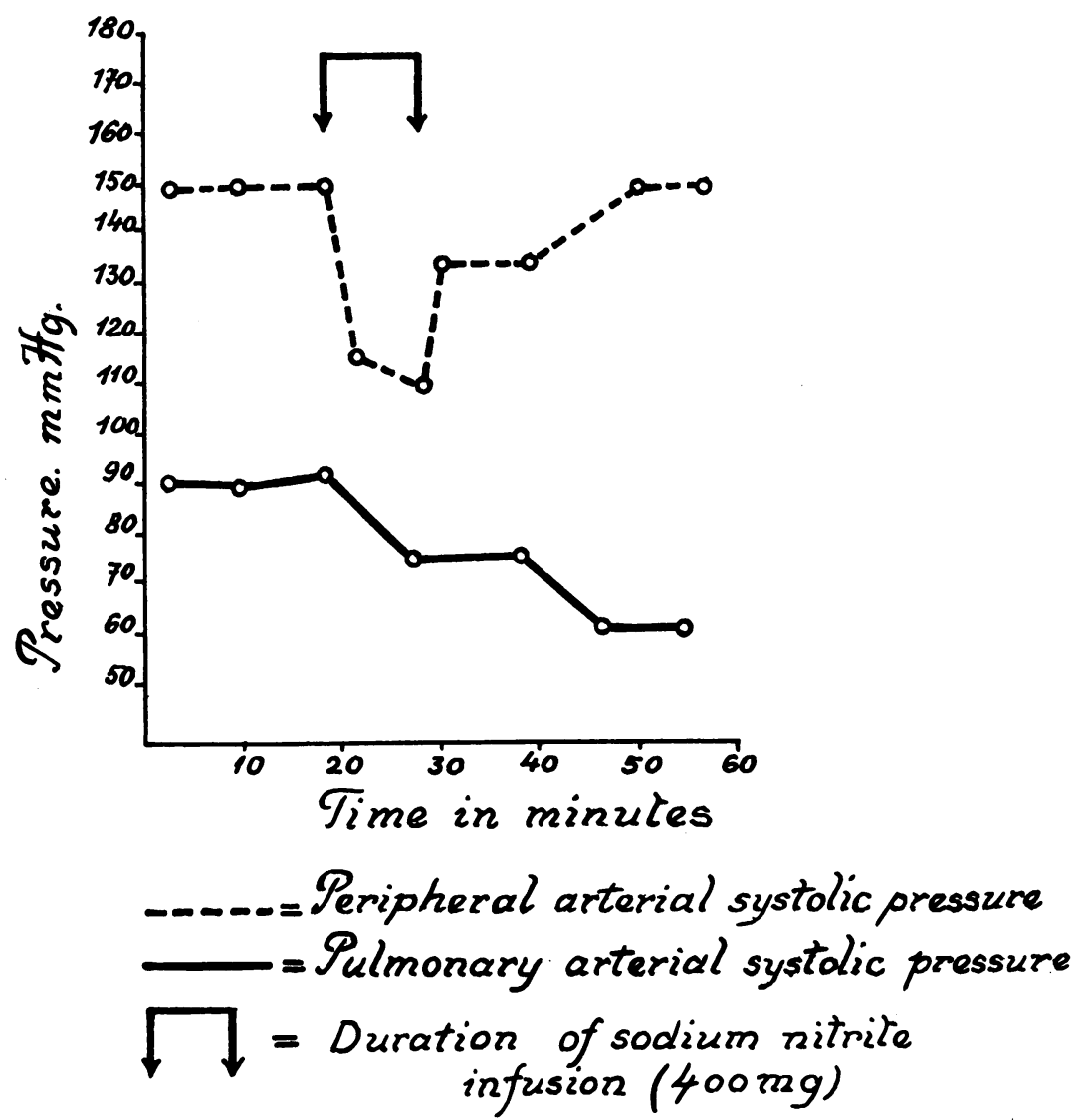

Fig. 5.-Simultaneous tracings of systemic and pulmonary arterial pressures following the administration of sodium nitrite in left heart failure.

that this phenomenon is due to a direct action on the receptor bodies of the pulmonary vessels. The decrease in pulmonary pressure during sleep strongly emphasizes the significance of the central nervous system as a possible source of that stimulus, which maintains pulmonary vasoconstriction in heart failure.

It is supposed that this vasoconstriction occurs in the arterioles of the pulmonary vascular tree. 
The physiologic and clinical importance of a static increase in pulmonary arteriolar resistance was excellently pictured by Lewis et al. (1952), in regard to mitral stenosis. A dynamic-i.e. functional-increase is of a still major importance. Its validity extends to both kinds of heart failure, as supported by the uniformity of the effects on pulmonary hypertension of muscular and neural blocking. The sequence of events may be described as follows.

Receptor bodies in the pulmonary vessels are sensitive to an elevation of pulmonary venous pressure. A slight increase in this pressure results through the sympathetic and central nervous system in a vasoconstriction of the pulmonary arterioles, with a consequent further increase in pulmonary arterial pressure. This creates a highly effective damper to sudden surges of output by the right ventricle. The extent to which this mechanism is helpful varies from patient to patient. An " overshoot" results in an extreme elevation of pulmonary artery pressure which, by protecting the capillaries from sudden increase in pressure, further decreases cardiac output and leads to an impairment of the right ventricle. In the absence of this mechanism the pulmonary capillaries are freely exposed to the high pressure in the pulmonary arteries, since egress of blood flow from the lungs is obstructed. These are the patients who experience frequent attacks of dyspnœa and œdema of the lungs (Lewis et al., 1952). This is the combination that occurs during sleep. This disturbed adaptation, promoted by the increased blood volume accompanying sleep (Menzel, 1940 ; Perera and Berliner, 1943), may be one of the many causes in the production of cardiac asthma and pulmonary odema in heart failure.

The cause of the excitation of the central nervous system remains unsolved. Anoxia is generally thought to be a direct chemical stimulus : its effect is uninfluenced by surgical or chemical sympathectomy.

The above observations are in good accordance with Speransky's view (1950) : "The participation of the nervous system of a complex organism extends without exception to all its functions."

\section{SUMMARY}

Administration of dihydro-ergotamine increases pulmonary arterial systolic pressure and resistance by constricting the pulmonary vessels. This pulmonary hypertension is abolished by the administration of sodium nitrite through its direct chemical effect on the pulmonary vessels. Pulmonary hypertension in heart failure also decreased after the administration of sodium nitrite. This was considered to be evidence of pulmonary vasoconstriction in heart failure. Tetra-ethylammonium bromide and dibenamine, by relieving neurogenic vasoconstrictor tone, also decreased pulmonary pressure and resistance in heart failure. A similar effect was observed during sleep, and was taken as evidence of the role of the central nervous system in the pathogenesis of pulmonary hypertension in heart failure.

The significance of these findings is stressed, with special reference to the genesis of paroxysmal nocturnal dyspnoa and pulmonary œdema.

Our thanks are due to Messrs. Sandoz Ltd., Basel, Switzerland, for liberal supply of dihydro-ergotamine, and to Mr. K. Szeitz for his invaluable help and assistance.

\section{REFERENCES}

Bayliss, R. I. S., Etheridge, M. J., and Hyman, A. L. (1950). Lancet, 2, 889.

Becker, D. L., Burchell, H. B., and Edwards, J. E. (1951). Circulation, 3, 230.

Bloomfield, R. A., Lauson, H. D., Cournand, A., Breed, E. S., and Richards, D. W. (1946). J. clin. Inves., $25,639$. Borden, C. W., Ebert, R. W., Wilson, R. H., and Wells, H. S. (1950). New Engl. J. Med., $242,529$.

Cournand, A. (1947). Bull. N.Y. Acad. Med., 23, 27. (1950) Circulation, 2, 641.

Daly, I. De B., and Hebb, C. O. (1942). Quart. J. exp. Physiol., 31, 211.

L (1952). Quart. J. exp. Physiol., 37, 19.

Dexter, L. (1952). Bull. N.Y. Acad. Med., 28, 90.

, Dow, J. W., Haynes, F. W., Whittenberger, J. L., Ferris, B. G., Goodale, W. T., and Hellems, H. K. (1950).

J. clin. Invest., 29, 602. 
Dirken, M. N. J., and Heemstra, H. (1948). Quart. J. exp. Physiol., 34, 193 ; 213 ; 227.

Dixon, W. E., and Hoyle, J. C. (1930). J. Physiol., 70, 1.

Doyle, J. T., Wilson, J. S., and Warren, J. V. (1951). Federation Proc., 10, 37.

Fejfar, Z., and Brod, J. (1951). Sbornik Lekar., 53, 99. (In Czech.)

Fowler, N. O., Westcott, R. N., Hauenstein, V. D., Scott, R. C., and McGuire, J. (1950). J. Clin. Invest., 29, 1387.

Gaylor, J. B. (1934). Brain, 57, 143.

Greene, D. G., and Bunnell, I. L. (1950). J. clin. Invest., 29, 818.

Halmágyi, D., Felkai, B., Iványi, J., and Hetényi Jr., G. (1952). Brit. Heart. J., 14, 101.

Hamilton, W. F. (1951). J. Allergy, 22, 397.

Hochrein, M. (1938). Klin. Wschr., 17, 438.

Issekutz Jr., B., Hetényi Jr., G., and Feuer, I. (1949). J. Physiol., 108, 32.

Kuntz, A. (1946). The Autonomic Nervous System. Ballière, Tyndall and Cox, London.

Larrabee, W. F., Parker, R. L., and Edwards, J. E. (1949). Proc. Staff. Meet. Mayo Clin., 24, 316.

Larsell, O., and Dow, R. S. (1933). Amer. J. Anat., 52, 125.

Lewis, B. M., Gorlin, R., Houssay, H. E. J., Haynes, F. W., and Dexter, L. (1952). Amer. Heart J., 43, 2.

Liljestrand, G. (1948). Arch. intern. Med., 81, 162.

Menzel, A. (1940). Klin. Wschr., 18, 29.

Motley, H. L., Cournand, A., Werkö, L., Himmelstein, A., and Dresdale, D. (1947). Amer. J. Physiol., $150,315$.

Nickerson, M., and Goodman, L. S. (1948). Federation Proc., 7, 397.

Parin, V. V. (1943/44). Amer. Rev. Soviet Med., 1, 251.

Parker, Jr., F., and Weiss, S. (1936). Amer. J. Path., 12, 573.

Pearce, J. W., and Whitteridge, D. (1951). Quart. J. exp. Physiol., 36, 177.

Perera, G. A., and Berliner, R. W. (1943). J. clin. Invest., 22, 25.

Puder, S. (1938). Tubercle, 19, 448.

- (1941). Virchow's Arch., 308, 153 ; 161.

Riley, R. L., Himmelstein, A., Motley, H. L., Weiner, H. M., and Cournand, A. (1948). Amer. J. Physiol., 152, 372.

Rappaport, M., and Sarnoff, S. J. (1949). Federation Proc., 8, 130.

Scherff, D., and Schönbrunner, E. (1937). Klin. Wschr., 16, 340.

Schwiegk, H. (1935). Pfüger's Arch., 236, 206.

Speransky, A. D. (1950). Grundlagen der Theorie der Medizin. Sänger, Berlin.

Sternberg, H., and Tamari, M. (1928). Arch. ges. exp. Path. Pharm., 136, 34.

Takino, M. (1933). Acta Scholae Med. Kyoto, 15, 321.

Vargas, J. J., and Savilla, V. S. (1949). Rev. Espanol. Fisiol., 5, 19. 